\title{
MENINGKATKAN SEMANGAT BELAJAR DAN TERUS BERKARYA BAGI PEMUDA-PEMUDI INDONESIA DIMASA COVID-19
}

\author{
Rollis Juliansyah ${ }^{1}$, Budianto ${ }^{2}$ \\ ${ }^{1)}$ Program Studi Ekonomi Pembangunan, Fakultas Ekonomi, Universitas Teuku Umar Aceh Barat \\ ${ }^{2)}$ Program Studi Akuntansi, Fakultas Ekonomi, Universitas Teuku Umar Aceh Barat \\ e-mail: rollisjuliansyah@utu.ac.id ${ }^{1}$, budianto@utu.ac.id ${ }^{2}$
}

\begin{abstract}
Abstrak
Kegiatan ini dilakukan dengan tujuan agar memberikan motivasi dan semangat dalam mengikuti pembelajaran meski dalam kondisi pandemik dengan memperhatikan aspek-aspek kesehatan. Sehingga dapat meningkatkan semangat dan termotivasi hingga mengahsilkan buah karya yang bermanfaat bagi agama, bangsa, dan Negara Indonesia. Dalam proses belajar mengajar diperlukan pemberian motivasi maupun peningkatan semangat bagi para peserta didik, agar tumbuh rasa percaya diri dan menumbuhkan ide-ide kreatif, sehingga dapat meningkatkan intelegensia peserta didik. Hal ini dapat dilakukan dengan banyak metode, baik dengan kegiatan diluar ruangan (kurikuler) maupun dengan meluangkan waktu dengan membagi cerita, pengalaman dan diskusi dengan peserta didik. Mengapa hal ini penting dilakukan? sebagaimana laju pertumbuhan penduduk yang terus meningkat dan penguatan kepemahan yang baik harus diberikan pada generasi muda, guna mendukung tercapainya pembangunan yang berkelanjutan dan pengelolaan sumberdaya manusia, hingga dapat berdampak pada pertumbuhan dan pengembangan wilayah selanjutnya melaui ide maupun aksi dari implementasi buah pikir yang kreatif dan membangun
\end{abstract}

Kata kunci: Covid-19, Pembangunan Manusia, Pendidikan

\begin{abstract}
This activity is carried out with the aim of providing motivation and enthusiasm in participating in learning even in pandemic conditions by paying attention to health aspects. So that it can increase enthusiasm and be motivated to produce works that are beneficial to religion, the nation and the State of Indonesia. In the teaching and learning process, it is necessary to provide motivation and increase in enthusiasm for students, in order to grow self-confidence and foster creative ideas, so as to increase students' intelligence. This can be done in many methods, both with outdoor activities (curricular) and by spending time sharing stories, experiences and discussions with students.

Why is this important to do? as the rate of population growth continues to increase and strengthening of good weaknesses must be given to the younger generation, in order to support the achievement of sustainable development and human resource management, so that it can have an impact on further regional growth and development through ideas and actions from the implementation of creative and constructive ideas.
\end{abstract}

Keywords: Covid19, Human Development, Education

\section{PENDAHULUAN}

Pendidikan adalah merupakan alat dalam mencapai pemenuhan kebutuhan kebutuhan hidup masyarakat, yang mana dengan pendidikan dapat melahirkan sebuah pengetahuan yang berdampak pada adanya inovasi dengan cara belajar. Jika ditinjau dalam skala ekonomi, memproduksi barang dan jasa perlu adanya human skill atau keterampilan yang diperoleh dari adanya pendidikan. Pendidikan merupakan aspek penting yang juga mendukung maju atau mundurnya sebuah wilayah, tak terkecuali pendidikan wajib hukumnya dalam tatanan kehidupan berbangsa, maupun dalam kita hidup beragama. Bila mana pendidikan telah terlaksana dengan baik, maka ada harapan timbulnya generasi mendatang dengan investasi manusia ini diharapkan mampu membawa perubahan dan perbaikan di masa mendatang. Hal ini tentunya dapat dicapai dengan adaya pendidikan dengan 
mengaplikasikan pendidikan dengan proses belajar. (Ula et al., 2020); (Syahril et al., 2020); (Benintendi et al., 2020) bahkan pendidikan juga mempengaruhi sisi lingkungan.

Akhir-akhir ini kita diselimuti oleh rasa cemas dan ketakutan akan virus Covid-19, yang dampaknya menimbulkan banyak kegiatan lumpuh total, banyak dari aktivitas masyarakat terhambat. Guna mencegah dan memutuskan rantai penyebaran virus tersebut, dengan metode menjaga kebersihan, cuci tangan, menggunakan masker, hingga jaga jarak. Tak hanya perekonomian global, dunia pendidikanpun terkena dampak dari kejadian penyebaran tersebut, yang memberlakukan metode belajar dari rumah (study from home) jika bagi mereka yang bekerja maka diberlakukan bekerja dari rumah saja (work from home). (Hanoatubun, 2020); (Marpaung et al., 2020);(Nurwati,2020) Salah satu dampak Covid-19 selain mengakibatkan penurunan kinerja ekonomi juga mempengaruhi sektor lain, seperti sosial, pendidikan dan lain yang ada di masyarakat. Hal ini tentu membuat kita semua kaget dan agak canggung dengan perubahan metode kerja dan belajar ini, hingga dapat menurunnya semangat dalam bekerja hingga kurang dan hilangnya motivasi dalam belajar bagi para siswa yang sedang menimpuh pendidikan di bangkubangku sekolah.

Sebagai penerus bangsa para pemuda yang tertuang dalam undang-undang kepemudaan bahwa mereka yang berusia 15-35 tahun. Jika ditinjau dari segi umur tersebut, banyak dari pemuda yang sedang tumbuh berkembang duduk di bangku sekolah hingga di bangku perguruan tinggi. Adanya kehilangan semangat belajar dan motivasi dalam menuntut ilmu tentu dapat menjadi malapetaka besar bagi kita semua di masa mendatang. Hal ini tentu berdampak pada kreativitas mereka dan mempengaruhi kemajuan dari sebuah tatanan berkehidupan mendatang, maka daripada itu proses menuntut ilmu harus dijaga dan diteruskan, agar terus hidup dan api semanagat tersebut tidak boleh padam, meski dengan kondisi dan rintangan apapun, demi keberlanjutan dan pembangunan manusia (human development suistainable)

\section{METODE}

Metode pelaksanaan kegiatan pengabdian ini dilakukan dengan cara sosialisasi dan diskusi interaktif dengan siswa-siswi, dengan menggunakan sara pendukung berupa pengeras suara dan pengayaan materi. Peserta pada kegiatan pengabdian ini adalah siswa Ilmu Pengetahuan Sosial yang duduk di kelas 3 atau kelas XII (dua belas). Kegiatan ini diawali oleh kepala sekolah dengan memberikan arahan dan sambutan, dilanjutkan oleh pemateri untuk menyampaikan materi kepada para siswa.

Para siswa/i menyambut dengan antusias materi yang disampaikan, yang ditandai dengan banyaknya pertanyaan-pertanyaan yang dilontorkan kepada pemateri, hal ini menjadi indikator penting dimana, para siswa semangat dan termotivasi dalam merespon dan manggapi materi yang sudah diulas. Di akhir sesi kegiatan, pemateri memberikan sesi kuis berhadiah, yangmana diberikan kepada para siswa-siswi yang bisa mengulas dan menjawab quiz dari pemateri.

Kegiatan pengabdian masyarakat ini dilaksanakan di Sekolah MAN 1 Aceh Barat yang beralamat di Drien Rampak, Johan Pahlawan Aceh Barat. Lokasi kegiatan ini merupakan inisiatif dari Kepala Sekolah setempat yang berkerja sama dengan Mahasiswa Himpunan Ekonomi pembangunan FE Universitas Teuku Umar (HIMEP FE UTU) dengan mengundang pemateri, untuk memberikan semangat belajar dan memotivasi para siswa pentingnya menjaga semangat belajar dan terus berkarya di masa Pandemi Covid-19 ini berlangsung.

\section{HASIL DAN PEMBAHASAN}

Kegiatan ini dilakukan dengan metode orasi dan diskusi dengan para siswa MAN 1 Aceh Barat dan di lanjutkan dengan sesi quiz berhadiah. Indikator penting dalam kegiatan ini berhasil adalah dengan adanya semangat dan siswa termotivasi yang ditandai dengan responsif dan antusias para siswa dan larut dalam suasa diskusi yang hangat, santai, dan serius. Adapun pembahasan yang diuraikan pada kegiatan ini, sebagai berikut:

1. Peran pemuda

Mengajak siswa-siswi aktif sebagai pemuda-pemudi pada kegiatan sosial dan terlibat aktif di masyarakat, yang mana tempat mereka berdomisili, sehingga menumbuhkan kepekaan dan kepedulian mereka terhadap lingkungan hidup, sosial dalam hidup bermasyarakat dan rasa tolong menolong. 
2. Memberikan studi kasus

Menyajikan para tokoh sebagai salah satu contoh yang sukses dan berhasil di kehidupan masyarakat dan mengubah dunia, sehingga dengan demikian mampu menumbuhkan semangat belajar dan para siswa-siswi termotivasi dalam proses belajar dan menuntut ilmu

3. Pendidikan sebagai jalan pembangunan

Dikarenakan para peserta dari kelas IPS, maka pemateri mengulas kebijakan-kebijakan yang terpaut dalam keilmuan sosial, seperti bagaimana pemerintah daerah mengambil peran dalam keuangan daerah untuk memajukan pendidikan daerah, mengajak mereka berfikir kritis dan lugas dalam mengurai permasalahn pembangunan tingkat daerah hingga nasional. Mengajak para siswa-siswi mengambil peran sebagai siswa yang belajar dan berkarya demi pembangunan dan kesejahteraan dari diri sendiri hingga dapat berguna bagi orang banyak.

\section{SIMPULAN}

Adapun simpulan dari kegiatan ini dapat berupa keberlanjutan dan dapat diteruskan di lain tempat pada pengabdian berikutnya. Hal ini diperlukan agar menumbuhkan motivasi dan membangun semangat para siswa-siswi dalam menempuh pendidikan sekarang, hingga pendidikan ketahap yang lebih tinggi. Dengan mebahas isu terkini dan memberikan motivasi yang mampu mengajak siswa-siswi termotivasi dan berfikiri kreatif maupun kritis di tengah-tengah masyarakat.

\section{SARAN}

Adapun tahap-tahap yang mungkin dapat dilakukan selanjutnya dalam menindaklanjuti terhadap hasil kegiatan ini adalah:

1. Menjaring ide dengan melakukan sharing atau diskusi bersama para dosen untuk meningkatkan peran aktif dalam merumuskan peningkatan semangat belajar dan menempuh pendidikan sebagai investasi manusia

2. Merumuskan kegiatan yang dapat meningkatkan motivasi dan semangat belajar bagi siswa-siswi dan menumbuhkan rasa kepedulian sesama

3. Melaksanakan kegiatan yang sudah ditentukan, baik itu kegiatan diskusi bersama siswasiswi maupun berupa pelatihan yang dilakukan dengan terstruktur dan terukur lainnya

\section{UCAPAN TERIMA KASIH}

Penulis mengucapkan terima kasih kepada instansi yang telah memberi dukungan dalam pengabdian ini dan Himpunan Mahasiswa Ekonomi Pembangunan Universitas Teuku Umar.Aceh Barat (HIMEP UTU)

\section{DAFTAR PUSTAKA}

Hanoatubun, S. (2020). Dampak COVID-19 Terhadap Perekonomian Indonesia. Journal of Education, Psychology and Counseling.

Marpaung, E. W. B. H., Adrian, L., \& Putri, S. A. (2020). Pandemi COVID-19: Dampak SosialEkonomi, Tantangan, dan Potensi Solusi. Demografi Sosial. https://doi.org/10.13140/RG.2.2.35252.68483

Nurwati, R. A. M. dan R. N. (2020). Dampak pandemi covid-19 terhadap peningkatan angka pengangguran di indonesia. Kesejahteraan Sosial.

Syahril, Saputra, J., Alisman, Affandi, Noviar, H., Juliansyah, R., \& Mahrizal. (2020). Supply chain strategy for world price of crude palm oil and its production on palm oil marketing margins in Indonesia: An application of pairwise granger causality. International Journal of Supply Chain Management, 9(1), 971-974.

Benintendi, R., Gòmez, E. M., De Mare, G., Nesticò, A., \& Balsamo, G. (2020). Energy, environment and sustainable development of the belt and road initiative: The Chinese scenario and Western contributions. Sustainable Futures. https://doi.org/10.1016/j.sftr.2020.100009.

Ula, T., Juliansyah, R., \& Risma, O,R (2020) Pengaruh Pajak Dan Retribusi Terhadap Belanja Langsung Dan Pertumbuhan Ekonomi Di Aceh. Jurnal Ekombis. https://doi.org/10.35308/ekombis.v6i1.2006 